\title{
仙台における建物疎開跡地処理と戦災復興 一疎開跡地の都市計画用地への転用をめぐる各事業の特徵と主体間の関係 - THE DISPOSITION OF BUILDING EVACUATION SITES IN SENDAI AND WAR-DAMAGE RECONSTRUCTION
}

- The projects and the relationship among public entities over diversion of evacuation sites to urban planning sites -

\author{
齋藤駿介*1 \\ Shunsuke SAITO
}

\begin{abstract}
The purpose of this paper is to clarify the state of the disposition of building evacuation sites in Sendai and its process and background while paying attention to business environments surrounding the disposition in central ministries and Sendai. Reflecting the policy of central ministries, in Sendai, it was planned to divert two evacuation sites to streets. However, due to differences in business environments, only one street was completed. Considering the relationship between war-damage reconstruction and prewar urban planning and building evacuation, three streets coincided with preceding plans, and prewar urban planning streets were succeeded to war-damage reconstruction through building evacuation.
\end{abstract}

Keywords : Building Evacuation, Sendai, Air Defense, War-Damage Reconstruction, Urban Planning, Home Ministry 建物疎開，仙台，防空，戦災復興，都市計画，内務省

\section{1. はじめに}

\section{1 研究の背景と目的}

第 2 次世界大戦末期、全国 279 都市の 61 万戸もの建物を破壊し た1)とされる建物疎開は戦時期日本の都市空間に多大な影響を与え た。また、建物疎開は平時において都市計画を担当していた内務省 によって立案されたため、戦時期において遅々として進まなかった 都市計画を推進する思惑が働いており、建物疎開区域指定は戦前都 市計画の影響を強く受けていた2)。さらに、戦災復興の際に建物疎開 跡地(以下では疎開跡地と記す)は都市計画用地一転用され、広幅員 街路などに姿を変えて、現在の都市空間にもその痕跡を残している。

このような都市計画上の重要性から、建物疎開に関寸る研究は都 市計画史分野において、早くからその研究の必要性が指摘されてき た3)。その研究関心の中心は建物疎開と戦災復興都市計画との関係 の解明にあり、先駆的な研究として石丸による広島・長崎を対象と した研究がある4)。石丸は空中写真や地図資料の詳細な分析を通し て、疎開跡地が戦災復興都市計画において広幅員街路や公園、広場、 河岸緑地に転用されたことを解明している。各都市によって転用の 程度に差はあるものの、東京5)や名古屋6)、横浜7においても疎開跡 地の都市計画転用が計画および実施されたことが明らかにされてい る。一方、京都を対象とした川口の研究は、建物疎開を総力戦体制 における国民動員の視点から捉えなおし、防空概念の誕生に始まる 建物疎開の歴史的経緯の解明とその都市社会への影響を明らかにし た8)。このほかにも、近年、戦後復興期の都市空間の実態解明が進め
られている都市史分野では、戦後復興期東京において、ターミナル 駅近傍の疎開跡地の存在が駅前の闇市形成の要因となり、新たな繁 華街形成の契機となったことが明らかにされている99。

このように建物疎開に関する研究は、研究対象都市および研究視 角ともに幅が広がりつつあるものの、その対象は建物疎開が早期か ら進展していた六大都市や広島・長崎の原爆被爆都市に限られ10)、 戦末期の短期間に、混乱した状況下で実施された都市は研究の対象 とされてこなかった。また、先行研究では戦災復興都市計画との関 係は考察されてきたが、建物疎開に先行する都市計画や防空施策と の関係は考察されなかった。こうした課題を踏まえ、筆者は先稿に おいて、戦末期のわずか 2 か月あまりの間に建物疎開が実施された 仙台を対象に、建物疎開の実態と先行する戦前都市計画・防空施策 との関係を考察した11)。その結果、建物疎開の実施による都市計画 の進展を期す内務省側の思惑と立ち遅れていた仙台市中心市街地の 都市計画を推進させたいという宮城県・仙台市側の思惑が結びつく ことによって、建物疎開は先行する戦前都市計画や防空施策の影響 を強く受けたことが明らかになった。

先稿では、建物疎開の事業経緯の詳細な把握と建物疎開をめぐる 各主体の動向の考察によって建物疎開の事業背景や疎開区域指定を 規定した要因を詳らかにすることを目指したが、この視角を踏まえ ると従前の建物疎開と戦災復興との関係についての考察にも課題が あることを指摘できる。先行研究では戦災復興都市計画の計画思想 や立案過程を明らかにすることを目的としているため、対象とされ 
るのは自ずと、結果的に都市計画転用が実施された疎開跡地だった。 また、分析も空中写真や計画図を用いて、建物疎開区域と戦災復興 都市計画を図上で比較する方法で行われている。したがって、疎開 跡地が都市計画用地へ転用される過程や実現に至らなかった計画は 等閑視されてきた ${ }^{12)}$ 。しかし、こうした転用過程や実現に至らなか ったものを含めた計画全体の把握は、戦中・戦後の都市空間に多大 な影響を与えた建物疎開を近代日本の都市史・都市計画史の中に位 置づけるうえで重要だと考えられる。

そこで、本稿では中央省庁の踈開跡地の処理方針や仙台における 戦災復興都市計画事業の進展などの建物疎開跡地処理を取り巻く事 業環境に着目しながら、仙台における疎開跡地処理の実態やその過 程 ・ 背景を明らかにすることを目的とする。仙台における疎開跡地 処理は戦災直後から構想され、戦災復興期にその一部が実施された。 また、事業の詳細については、中止された計画も含めて宮城県や仙 台市の公文書に記録が残されている。したがって、実施に至らなか った計画も含めて、計画立案の経緯や背景、事業化の過程などを把 握することで、疎開跡地の都市計画用地一の転用過程の全容を解明 することができる。また、先稿で指摘した仙台における建物疎開と 戦前都市計画の連続性を踏まえると、先行研究では扱われてこなか った、戦前から戦後の各計画(戦前都市計画・建物疎開・戦災復興)間 の関係や連続性についても考察を加えることができる。さらに、仙 台の戦災復興都市計画は市街地に緑豊かな植樹帯を持つ広幅員街路 を整備し、「杜の都」の重要な景観要素を形成したとして、その事業 水準の高さが評価されてきたが13)、旧軍用地の都市公園への転用と 公園緑地系統の関係を考察した研究14)のほかには、その詳細は解明 されていない15)。したがって、本稿には仙台の戦災復興の一端を解 明するという研究意義も認められる。

本稿では、まず第 2 章において、仙台における疎開跡地処理を考 察する前提として、内務省をはじめとした中央省庁における疎開跡 地処理の政策動向と疎開跡地処理と密接に関係寸る戦災復興都市計 画の展開を解明する。続いて第 3 章では戦時期仙台における建物疎 開の概要と終戦前の疎開地利用計画を明らかにする。そして、第 4 章では戦災復興期仙台における疎開跡地の都市計画転用の計画およ び実施の状況と、その背景にある中央省庁の政策動向や仙台の戦災 復興都市計画の方針などの疎開跡地処理を取り巻く事業環境との関 係を解明する16)。

\section{2 研究方法と資料}

本研究は主として文献・史資料調查によっている。疎開跡地処理 の全国的な動向や方針の把握には、『内務省史』や『戦災復興誌』な どの文献や国立公文書館所蔵の公文書などの史資料を用いた。

仙台における戦災復興や疎開跡地処理に関しては、宮城県公文書 館や宮城県都市計画課、仙台市役所、仙台市博物館所蔵の公文書や 議会議事録、地元紙の『河北新報』、『仙台市戦災復興誌』や『仙台 市史』などの仙台市発行の文献、地図などの史資料を用いた。また、 疎開跡地処理の実施状況の確認には米軍撮影の空中写真も活用した。

\section{2. 戦災復興と建物疎開跡地}

\section{1 中央省庁の建物疎開跡地処理の方針}

疎開跡地の戦後処理は防空行政全般を所管していた内務省が主導 した。1945 年 8 月 31 日に廃止された防空総本部17)か建物疎開の
残務を引き継いだ内務省国土局18)は、同年 9 月 20 日には早くも疎 開跡地処理に関寸る通㭊を出している19)。この「建物疎開跡地に関 する件」20)では、疎開跡地を都市計画用地として転用する方針が示 された。この通牒は地方公共団体に対して、買収済みの疎開跡地は 空地として保有し続け、賃借中の疎開跡地のうち都市計画施設とし ての利用が見込まれるものは賃借し続けるように命じた。また、国 や私人が保有する疎開跡地についても、空地として存置させること とした。さらに、戦災都市では利用見込みの有無を問わず、戦災復 興都市計画の決定まで賃借地を存置するように命じた。このように、 終戦直後から内務省は疎開跡地を都市計画用地として読み替える方 針を明確に示していた。

この方針は同年 12 月 30 日に閣議決定された「戦災地復興計画基 本方針」21)にも示され、戦災復興都市計画において疎開跡地を都市 計画用地に転用することが決定的となった。このとき、土地区画整 理区域内の疎開跡地は地方公共団体がすべて買収することとされた。 また、区画整理区域外および非戦災都市の疎開跡地も都市計画上必 要なものは地方公共団体が買収し、その経費に対して国庫補助を交 付することが定められた。

翌 1946 年 4 月 11 日には内務省国土局計画課長から「建物疎開跡 地処理に関する件」22)が発せられ、疎開跡地のうち都市計画上必要 な区域については、同年 7 月 31 日までに都市計画決定を行うよう に促された。この背景には終戦に伴う法的根拠の喪失があった。建 物疎開事業の根拠法は防空法だったが、終戦に伴い、1946 年 1 月 30 日に廃止されていた。したがって、本来であれば疎開跡地は所有 者に返却される心゙きだった。しかし、内務省は疎開跡地の都市計画 転用を推進するために、疎開跡地に対しては例外的に、疎開区域指 定および区域内の建築禁止の根拠だった防空法第 5 条の 5 の規定の 効力を同年 7 月 31 日まで延長していた。つまり、内務省は疎開跡 地に対する法的根拠を特例的に延長することで、疎開跡地の都市計 画決定を行う時間稼ぎをしていたのである。また、防空法の廃止に 伴い打ち切られる予定だった跡地の賃借費に対する国庫補助(賃借 費の 3 分の 2)を延長する財政措置も講じた ${ }^{23)}$ 。

このように疎開跡地の戦後処理は、戦時期に建物疎開を所管した 内務省が主導したが、他の関係省庁もまた、その処理方針の決定に 関与した。内務省・運輸省・戦災復興院の三者は戦災復興都市計画 と鉄道復旧計画の調整を図ることを目的に協議を行い、1946 年 7 月 15 日に「戦災地及建物疎開跡地に於ける運輸省計画と都市計画に関 する申合の件」24)を発した。この通牒では疎開跡地について次のよ うに定めている。

1 施設計画

口その他(イは省略)

1 鉄道線路沿線両側には原則として適当なる幅員の道路又は緑 地を存置すること。

2 区画整理を施行する区域内において新幹線その他鉄道路線の 施設に関する実施計画ある場合は、計画線両側に道路を敷設 すること。

この規定によって、疎開跡地のうち鉄道沿線に存するものについ ては道路または緑地として計画することとされた。この背景には、 戦時中に鉄道防護を目的とした建物疎開が多くの都市で行われ、多 くの鉄道沿線疎開空地帯25)が日本各地の都市に存在したことがある 
と考えられる。そのため、運輸省の側としては戦災復興を機に、疎 開跡地を「新幹線」計画や複線化などに必要な用地として確保した いという思惑があったと推測される。なお、第 2 項の「新幹線」は 現在の意味での新幹線を直接的に指寸わけではなく、戦時中に輸送 力増強と大陸連絡を目的として計画された、いわゆる弾丸列車計画 (新幹線計画・広軌別線計画)や複線化などの幹線輸送力増強計画を 意味していると考えられる26)。このほかにも、警視庁消防部は消防 上の見地から防火帯の確保を目的として疎開跡地の空地ないしは緑 地、街路用地としての存置を戦災復興都市計画に対する要望事項と して戦災復興院に建議していた27)。

以上のように、戦時期に建物疎開を所管していた内務省は終戦直 後から一貫して疎開跡地の都市計画用地としての転用を推進し、疎 開跡地の賃借や買収に対する国庫補助や法規定の特例的延長などの 措置を講じていた。このような内務省の方針は「戦災地復興計画基 本方針」にも盛り込まれ、戦災復興都市計画において同様の方針が 採られることになった。また、鉄道沿線疎開空地帯の処理に関して は、鉄道の復旧を所管する運輸省や戦災復興を所管する戦災復興院 も都市計画および鉄道用地としての転用を目論んでいた。

\section{2 戦災復興都市計画と生産都市再建整備事業}

前節で明らかにした経過をたどって都市計画用地への転用が決定 的となった疎開跡地は、戦災都市においては主として戦災復興都市

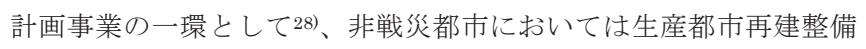
事業として事業化が進められた。

前者の戦災復興都市計画は当初、従前の一般都市計画を担当して いた内務省国土局計画課が担当した29)。同課は終戦直後から戦災復 興事業の基本方針を検討し30)、1945 年 9 月には成案を得た。それと 同時に戦災復興事業の機構整備も構想され、同年 11 月 5 日には内 閣に戦災復興院が発足した ${ }^{31}$ 。これによって戦災復興都市計画事業 の所管は戦災復興院となり、内務省国土局計画課は疎開跡地の整備

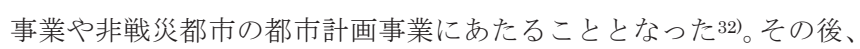
同年 12 月 30 日に前述の「戦災地復興計画基本方針」が閣議決定さ れ、過大都市の抑制と地方中小都市の振興を方針とした戦災復興都 市計画が実施されることになった。この方針の影響もあり、事業主 体は原則的に市町村長とされた。また、同事業は戦災復興の基盤と して土地区画整理を重視し、その円滑な実施のために 1946 年 9 月 10 日に特別都市計画法が制定された ${ }^{33)}$ これを受け、同年 10 月 9 日に全国各地の戦災都市のうち 115 都市が同法の指定を受け、戦災 復興都市計画は各地でその緒についた ${ }^{34)}$

後者の生産都市再建整備事業は防空総本部から建物疎開の残務を 引き継いだ内務省国土局計画課が所管した。この事業は「疎開跡地 等で都市計畫上存置を必要とし、且つ緊急必需物資(中略)の生産力 増強に直結するもの」を対象とした都市計画事業だった ${ }^{35)}$ 。事業対 象とされた 166 都市の中で戦災都市は 12 都市であり、基本的には 非戦災都市を対象とした事業だった ${ }^{36)}$ 。つまり、生産都市再建整備 事業は非戦災都市における疎開跡地の都市計画転用を行うための事 業だった。ただし、同事業はその対象を踈開跡地に限定していたわ けではなく、非戦災都市における一般都市計画にも用いられた ${ }^{37) 。}$

以上の 2 事業に加え、内務省国土局計画課による建物疎開跡地整 備事業も実施され、疎開跡地の都市計画転用に活用された。この事 業は戦災都市にありながら、土地区画整理区域外であるといった事
情により、戦災復興都市計画事業に包含されなかった疎開跡地整備 などに対して適用された38)

\section{3 戦災復興都市計画の事業化}

特別都市計画法の適用を受けた戦災都市では、同法の制定後に定 められた計画標準にのっとり、新たな都市計画が構想され、各種の 都市計画決定を行っていった。その事業化に際しては、土地区画整 理事業に対して昭和 20 年度は 9 割、昭和 $21 \sim 23$ 年度は 8 割の国 庫補助を支出するなど、政府による強力な財政措置が講じられた ${ }^{39)}$ 。 しかし、土地区画整理事業の相次ぐ遅延や急激なインフレによる物 価高騰などにより、事業の進展に支障をきたすようになった。折し も 1948 年 12 月の経済安定 9 原則とその具体化を図ったドッジ・ラ イン(1949 年 3 月)によって財政支出の削減が強く求められる情勢に あり、戦災復興都市計画も再検討を余儀なくされた。その結果、各 地の戦災復興都市計画は縮小された。ただし、その縮小幅は一律で はなく、早期から事業が進行していた都市では小さいが、東京など の事業が遅れていた都市では大幅に縮小された40)。

\section{3. 仙台における建物疎開と戦中の疎開地利用}

戦時期仙台における建物疎開は戦局の覀化を背景として、1945 年 6 月 25 日から 3 次にわたって、急速に計画、実施された 411 。また、 その最中にあった 7 月 9〜10 日には仙台空襲の被害を受け、建物疎 開の方針・目的は転換を余儀なくされ、疎開地を対象とした復興計 画も立案された。本章では空襲被災後における建物疎開の状況と終 戦以前に立案された復興計画における疎開地利用を明らかにする。

\section{1 疎開計画の策定と仙台空襲}

1945 年 6 月 25 日に実施が決定した第 1 次建物疎開は仙台市内の 1,076 戸を対象とした。その区域指定は消防道路敷設や工場・鉄道 の防護など、生産防空や都市機能防護を強く意識したものだった ${ }^{42}$ (図 1)。また、7 月 9 日には堅牢建築物の防護を目的とした第 2 次建 物疎開の実施が決定した(図 1)。

しかし、上述の第 $1 \cdot 2$ 次建物疎開実施の最中にあった、 7 月 9 日 深夜から翌 10 日未明にかけて、仙台は米軍による空襲を受けた。 この仙台空襲によって中心市街地一帯の約 500ha が廃墟と化し、焼 失戸数・被災人口はそれぞれ 11,933 戸(全市戸数の約 $23 \%$ ) ・ 57,321 人(全市人口の約 $26 \%$ )に及び、1,066 名の犠牲者を出すなど、多大 な被害が生じた $\left.{ }^{43}\right)$ (図 1)。その後も小規模な爆撃が続く中で、焼跡 の整理や被災者の住宅確保、食糧不足の解消は急務となった。

こうした情勢下で、建物疎開の方針も大きく転換した。7月 29 日 に実施が報道された第 3 次建物疎開では、喫緊の課題である再空襲 時の被害軽減を強く意識した区域指定が行われた44)。さらに、次節 で詳述するように、疎開本来の目的である「防空」から離れ、被災 者住宅建設用の建築資材確保を目的とした建物疎開も計画されるよ うになった ${ }^{45)}$ 。

\section{2 空襲後の復興計画と建物疎開}

このように被災者の住宅確保と食糧不足の解消という 2 つの課題 に直面した空襲被災後の仙台では、それぞれの課題に呼応した応急 的な復興計画が被災直後から立案されていた。

最初期の応急的な復興計画は食糧不足の解消に主眼を置いたもの が多かった。仙台の復興計画が初めて取り沙汰された46)、7 月 16 日 の『河北新報』は、焼け残った堅牢建築物の官公庁への転用やバラ 
ックの建築を許可する地区の指定を行うととも に、それらの用途に供しない地区は全て農耕地 区に指定することで、食糧増産に努める方針を 県は定めたと報じた47)。この方針は県の戦災処 理委員会によって具体化が進められ、焼跡の金 属回収などの清掃作業が完了した地区から開墾 作業にあたり、農耕は国民義勇隊や戦災残留者 に行わせることとされた48)

空襲被災地の農耕用地としての利用が計画さ れる中で、被災者の住宅確保に関する計画もま た構想され始めた。7月 20 日の第 1 回戦災処理 委員会では、住宅営団に 1,000 戸程度の戦時住 区49)を建設させる方針が定められた50)。その後、 被災者住宅建設計画の具体化が進み、宮城県計 画課・兵事厚生課および仙台市都市計画課によ って、被災者用の簡易住宅 1,000 戸を市内 4 か 所に分けて建設する計画が立案された51) (図 1 ・ 表 1)。簡易住宅は仙台市の第 $1 \cdot 2$ 次建物疎開 対象家屋のうち、被災を免れた 600 戸を住宅営 団が取り壞し、その資材を活用して 1 戸 10 坪 程度で建設する予定だった。この計画が立案さ れた直後に、簡易住宅群建設とともに街路敷設 も盛り込んだ包括的な復興計画が仙台市都市計 画課によって立案された52)。この計画では前述 した簡易住宅群の戦時住区への指定を目指し、 厚生施設の整備も行う方針が定められた。また、 このとき計画された 5 本の街路は、4 か所の簡 易住宅群を相互に連絡するように路線が選定さ れた(図 1 ・表 2)。さらに、これらの街路には郊 外一の連絡路としての役割も期待されており、 単なる応急策ではなく都市計画的な見地からの 検討も施されていたことが窥える。それを裏付 けるように、いずれの街路も後の戦災復興都市 計画で実現しており、戦災復興の目玉ともいう べき重要な街路が仙台空襲直後の早期から計画 されていたことを示している。中でも、立町線 の終点は「X 橋疎開空地」とされ、最初期の疎 開地の利用計画だった。また、東五番丁青葉荘 線と細横丁線は建物疎開区域と一致しているた め、これら 2 路線も疎開地を利用寸る計画であ った可能性がある53)。

8 月になると、被災者住宅の建設計画のみな らず、戦災地・疎開地の農耕地利用計画も具体 化が進んだ。戦災地の緑化計画(農耕地転用計 画) は宮城県農務課・農業会・義勇隊本部および 仙台市農林課によって立案が進められ、8 月 4 日には第 1 期計画として 50 町歩の開墾が計画 された ${ }^{54)}$ さらに、同月 13 日には緑化計画の成 案が完成し、公会55)ごとに設置された国民義勇 隊や学徒隊によって開墾が開始された56)。なお、
Table1 Placement plan of temporary housing right after the war damage in Sendai 表 1 仙台における戦災直後の簡易住宅群配置計画

\begin{tabular}{|c|c|c|}
\hline $\begin{array}{l}\text { 記号 } \\
\text { Sign }\end{array}$ & $\begin{array}{c}\text { グループ名 } \\
\text { Group }\end{array}$ & 建設予定地 \\
\hline 1 & $\begin{array}{c}\text { 第1群 } \\
\text { 1st group }\end{array}$ & $\begin{array}{c}\text { 西公園(1)、立町国民学校(2)、仙台中学校(3)、常盤木女学校(4) } \\
\text { Nishi (west) park, Tatemachi Elementary School, Sendai Junior High School, } \\
\text { Tokiwagi Girls' School }\end{array}$ \\
\hline 2 & $\begin{array}{c}\text { 第2群 } \\
\text { 2nd group }\end{array}$ & $\begin{array}{c}\text { 北五番丁国民学校(5)) } \\
\text { Kitagobancho Elementary School }\end{array}$ \\
\hline 3 & $\begin{array}{c}\text { 第3群 } \\
\text { 3rd group }\end{array}$ & $\begin{array}{l}\text { 勝山公園(6)など } \\
\text { Katsuyama park }\end{array}$ \\
\hline 4 & $\begin{array}{c}\text { 第4群 } \\
\text { 4th group }\end{array}$ & $\begin{array}{c}\text { 第一高等女学校(7)、仙台女学校(8) } \\
\text { Daiichi (1st) Girls' Junior High School, Sendai Girls' School }\end{array}$ \\
\hline
\end{tabular}

*出典 :『河北新報』1945 年 7 月 26 日、第 2 面 Source: “Kahoku Shimpo”(Local newspaper), 1945.7.26, p.2.

Table2 Reconstruction plan right after the war damage in Sendai 表 2 仙台における戦災直後の復興計画

\begin{tabular}{|c|c|c|c|c|}
\hline $\begin{array}{l}\text { 記号 } \\
\text { Sign }\end{array}$ & $\begin{array}{c}\text { 路線名 } \\
\text { Route name }\end{array}$ & $\begin{array}{c}\text { 幅員 }(\mathrm{m}) \\
\operatorname{Width}(\mathrm{m})\end{array}$ & $\begin{array}{l}\text { 区間 } \\
\text { Route }\end{array}$ & $\begin{array}{c}\text { 現在の街路名 } \\
\text { Current street name }\end{array}$ \\
\hline A & $\begin{array}{c}\text { 立町線 } \\
\text { Tatemachi Line }\end{array}$ & 30 & $\begin{array}{c}\text { 中ノ瀬橋 元寺小路·日吉町 X橋疎開空地 } \\
\text { From Nakanose Bridge to Evacuated area in X- } \\
\text { Bridge via MototeraKoji and Hiyoshicho }\end{array}$ & $\begin{array}{c}\text { 広瀬通 } \\
\text { Hirose Ave. }\end{array}$ \\
\hline B & $\begin{array}{c}\text { 東五番丁青葉荘線 } \\
\text { Higashigobancho-Aobaso Line }\end{array}$ & 15 & $\begin{array}{c}\text { 北一番丁上杉山通角 多門通裏五番丁 } \\
\text { From corner of Kitaichibancho-Kamisiyama St. } \\
\text { to Tamon St.-Uragobancho }\end{array}$ & $\begin{array}{c}\text { 愛宕上杉通 } \\
\text { Atago-kamisugi Ave. }\end{array}$ \\
\hline C & $\begin{array}{c}\text { 細横丁線 } \\
\text { Hosoyokocho Line }\end{array}$ & 30 & $\begin{array}{c}\text { 北六番丁 控訴院(9)) } \\
\text { From Kitarokubancho to court of appeal }\end{array}$ & $\begin{array}{c}\text { 晚翠通 } \\
\text { Bansui Ave. }\end{array}$ \\
\hline D & $\begin{array}{c}\text { 定禅寺通線 } \\
\text { Zyozenzidori Line }\end{array}$ & 20 & $\begin{array}{c}\text { 図書館(10)前 元常盤丁 } \\
\text { From library to Mototokiwacho }\end{array}$ & $\begin{array}{c}\text { 定禅寺通 } \\
\text { Zyozenzi Ave. }\end{array}$ \\
\hline $\mathrm{E}$ & $\begin{array}{c}\text { 花京院通線 } \\
\text { Kakyoindori Line }\end{array}$ & 22 & $\begin{array}{c}\text { 錦町育英中学(11)前～市電原町線 } \\
\text { From Ikuei Junior High School in Nishikimachi } \\
\text { to Haranomachi Line }\end{array}$ & $\begin{array}{c}\text { 花京院通 } \\
\text { Kakyoin Ave. }\end{array}$ \\
\hline
\end{tabular}

*出典: 『河北新報』1945 年 7 月 29 日、第2 面 Source: “Kahoku Shimpo”(Local newspaper), 1945.7.29, p.2.

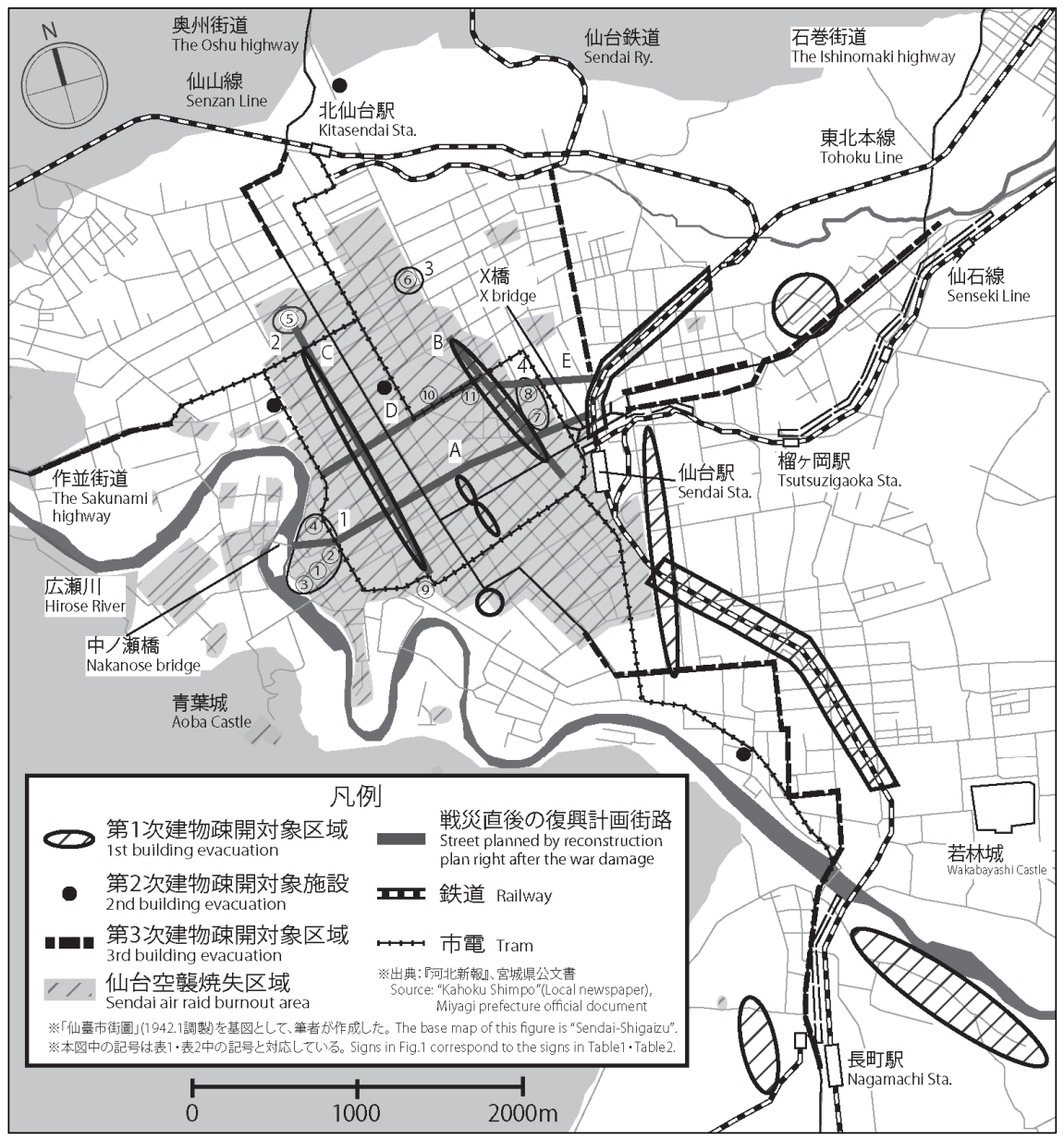

Fig.1 Designation of building evacuation area in Sendai and reconstruction plan right after the war damage

図 1 仙台における建物疎開指定区域と戦災直後の復興計画 
緑化地区は戦時住区や主要街路の計画を勘案して、公会ごとに指定 された。

こうして、仙台の復興計画は農業系部署による戦災地・疎開地の 農耕地利用計画および都市計画系部署による簡易住宅群・街路の建 設計画の 2 系統に分かれて立案が進められたが、最終的には「戰災 地應急復興対策要領」に結実した57)。この要領では両者を包含して ひとつの復興計画としてまとめられており、基本的には前述の計画 内容を踏襲している。しかし、戦災復興の妨げとなることを防ぐた めに、建築線の指定や建築物の新築に対する制限などの建築規制を 加える方針と建物疎開を実施した敷地には建築を認めない方針も新 たに示されている58)。後者に関しては、疎開地の将来的な都市計画 用地として転用を見込んだものと考えられる。

以上のように、被災者の住宅確保への対処が検討され始めた 1945 年 7 月下旬になって、仙台では疎開地の街路への転用が計画された。 それと同時に建物疎開は、従来の防空だけでなく、建築資材確保を も目的とするように変容した。さらに、仙台空襲直後の復興計画の 最終形である「戰災地應急復興対策要領」では、将来的な戦災復興 の円滑な実施や疎開地利用を期する条項が設けられた。また、都市 計画用地一の転用だけでなく、食糧増産を目的とした疎開地の農耕 地への転用も計画された。

\section{4. 仙台における建物疎開跡地処理}

\section{1 戦災復興都市計画の策定}

3.2 節で明らかにしたように、仙台の復興都市計画案は空襲被災 直後から仙台市都市計画課によって立案され、県の「戰災地應急復 興対策要領」に結実していた。ただし、これらの案はあくまでも応 急対策であり、本格的な復興都市計画は終戦後に改めて検討される こととなった。

当初、戦災復興都市計画は従来の一般都市計画と同様に県が事業 主体となって行われる予定で、宮城県土木部計画課が中心となって 計画が策定された59)。その復興計画は 1945 年 11 月 15 日の仙台市 戦災復興計画懇談会で公表された60)。この計画の目玉は中心部で交 差する東西・南北 2 本の $50 \mathrm{~m}$ 街路で、東西線は元寺小路から西公 園までの路線(仙台空襲直後の復興計画案における立町線)、南北線 は県庁前から北目町通までの路線(東二番丁線)だった。また、仙台空 襲直後の復興計画案にあった街路は花京院通線を除いてす心゙てが計 画されたほか、市電環状線の走る街路の拡幅やのちの戦災復興都市 計画における仙台駅川内線(現青葉通)にあたる街路も計画された。 このように、街路計画の面では空襲直後の計画の踏襲性が強く、建 物疎開対象区域の計画はすべてが継承された。また、公園緑地は駅 前・県庁前・西公園周辺にそれぞれ大公園を設け、県庁前公園と西 公園を結ぶ $60 \mathrm{~m}$ 幅の緑地帯(表小路緑地)が計画されたほか、連合公 会ごとに小公園を設けるなど、大々的に緑地を整備する方針だった。

こうした県を主体とした検討とは別に、民間での復興構想も存在 した。同年 11 月に河北新報社 - 大日本技術会東北支部の共催、宮城 県の後援で「仙台市戦災復興計画懸賞募集」が行われた ${ }^{61)}$ 。計画方 針として保健・防災を主眼とし、公園緑地を系統的に配置(計画市街 地の $10 \%$ 程度)することなどを定めた。この懸賞には 48 点の応募が あり、10 名の入賞作品(1 等は住宅営団仙台支所工務課長の長谷川 英三氏)が選定された62)。
こうして官民両者における復興計画策定の熱が高まっていた折に、 前述した「戦災地復興基本方針」が閣議決定され、事業主体は原則 として市町村長とされた。これを受け、仙台市でも事業主体の再検 討が行われた。仙台市当局としては事業遂行の容易さや、市主体と した場合の財政不安を理由に県施行のままとする方針だったが、市 会は市が主体となって地元の意思を反映させながら行うべきだとし た ${ }^{63)}$ 。その結果、1946 年 2 月 6 日の市会全員協議会において、仙台 市が事業主体となることに決定した。

そのため、復興街路・公園計画は仙台市において再審議されるこ ととなり、1946 年 4 月に仙台市復興委員会が設置された ${ }^{64)}$ 。再審議 の結果、市復興委員会の最終案は同年 8 月 13 日に決定した65)。こ の最終案では一部の街路は幅員を縮小され、表小路緑地も廃止され、 代替として定禅寺通に幅員 $12 \mathrm{~m}$ の緑地帯が新たに計画された。ま た、 $50 \mathrm{~m}$ 街路も東二番丁線・元寺小路川内線から東二番丁線・仙台 駅川内線に変更された。一方、街路路線数は県案に比して増加し、 既存路線も延長された。このように、基本的には県案を踏襲しつつ も、全体的な見直しが行われ、周辺部との連絡を意識した計画に変 容したといえる。その後、この最終案は 9 月に戦災復興院の審査を

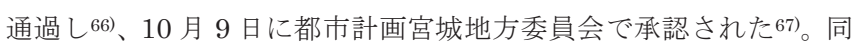
日には特別都市計画法の指定も受け、11月 11 日に「戦災復興院告 示第二百四十四号」によって、街路・公園計画が確定した68)。なお、 戦災復興院の審查から告示に至る過程で街路計画が追加されており、 4.2 .2 項で詳述する連坊小路南染師町線も市最終案には存在せず、こ の過程で追加されている。

以上の過程を経て決定した街路計画は防災に重点をおき、防火帯・ 避難路としての活用も見込んだ中心市街地の広幅員街路が重視され た。また、将来的な交通量の増大や郊外との連絡も考慮して合計 25 路線が策定された69)。これらの路線は土地区画整理事業の対象とな った戦災焼失区域を中心に指定されていた。

\section{2 建物疎開跡地の街路転用}

前述の通り、戦災復興において疎開跡地は街路として転用された 場合が散見されるが、仙台においても複数の箇所で転用が計画され、 一部が実施へと至った(図 $2 \cdot$ 表 3 )。それらは対象地域に応じて、戦 災復興都市計画事業の一環として計画されたものもあれば、内務省 国土局計画課所管の疎開跡地処理事業として計画されたものもある。 以下では、街路への転用が判明、もしくは推測される区域ごとに、 その計画の詳細および背景、実施状況を明らかにする。

\subsection{1 長町八本松における転用}

長町八本松では第 1 次建物疎開の際に、軍需工場防護を目的とし て、重要施設周辺疎開が 98 戸の家屋を対象として行われた。

長町八本松の踈開跡地は 1946 年から都市計画への転用が計画さ れ、国庫・県費補助を前提として市の同年度予算に組み込まれた70)。 翌 1947 年にはその一部が完成し71)、1948 年に全線開通した。

長町地区は戦災非焼失区域であるため、戦災復興土地区画整理事 業の対象区域とはならなかった。それゆえ、長町八本松線は戦災復 興都市計画街路には指定されなかった。しかし、長町八本松線に対 しては戦災復興都市計画事業とは別に、単独で「長町八本松線疎開 跡地処理連絡街路事業」が計画され、実施に至った。この事業は国 庫および県費補助を受けて施行されたが、前述の事業名は宮城県公 文書館に所蔵されている県費補助関係書類72)に記されていたもので 
ある。したがって、現時点では国庫補助事業と しての事業名は不明である。しかし、長町八本 松線が戦災復興都市計画事業に包含されてい ないことを考えると、当事業は 2.2 節で明らか にした疎開跡地処理の各事業のうち、内務省国 土局計画課所管だった生産都市再建整備事業 または建物疎開跡地整備事業によっていたと

\section{考えられる。}

図 3 は事業計画図である73)。長町八本松線は 広瀬橋南詰から東北本線をくぐり、萱場製作所 などの軍需工場群の北側を走り、現在の国道 4 号線バイパス付近へ至る街路である。その一部 は戦前都市計画街路の土樋下河原線と一致し、 全体としては同路線を東南へ延長した路線に なっている。

この事業は国庫・県費補助を受けていたが、 図 3 左側(原図では青色彩色)が国庫補助区間、 図 3 右側(原図では赤色彩色)が県費補助区間だ った。このうち県費補助区間に関しては、前述 の県公文書が残されており、その詳細が判明し ている。県費補助区間は幅員 $7 \mathrm{~m}$ 、総延長 $700 \mathrm{~m}$ で、路面には砂利敷きが施され、街路の端には $1 \mathrm{~m}$ 幅の側溝が設けられた ${ }^{74)}$ 。県費補助額は県 費補助区間の総事業費 52 万円の $25 \%$ にあたる 13 万円だった。なお、この事業費には用地買収 費は含まれておらず、用地取得は 1947 年度事 業として国庫補助を得て市が実施している75)。

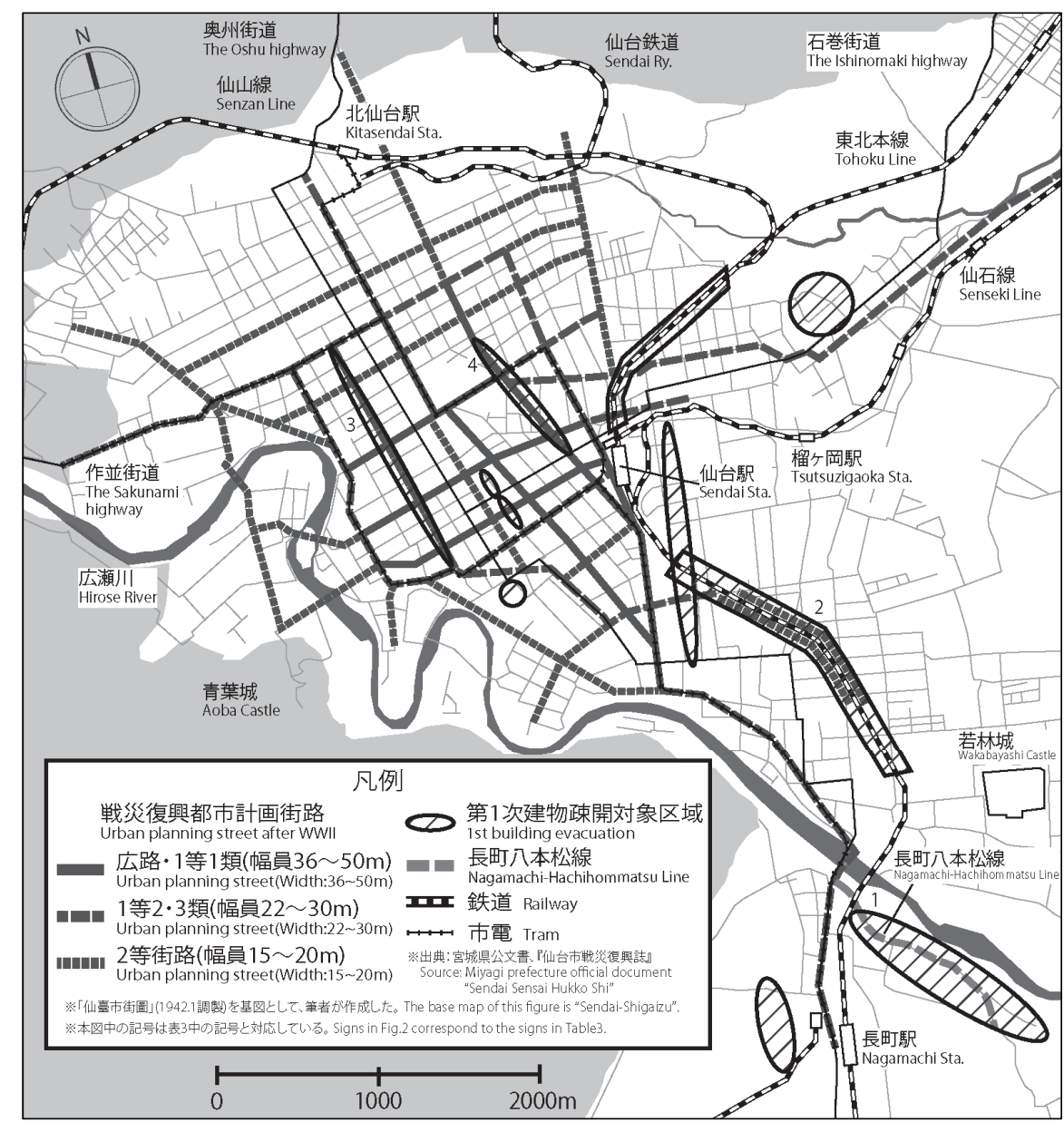

Fig.2 Diversion of building evacuation site to street in Sendai 図 2 仙台における建物疎開跡地の街路転用

Table3 Relationship between the diversion of building evacuation site to street and the prewar urban planning 表 3 建物疎開跡地の街路転用と戦前都市計画との関係

\begin{tabular}{|c|c|c|c|c|c|}
\hline $\begin{array}{l}\text { 記号 } \\
\text { Sign }\end{array}$ & $\begin{array}{l}\text { 建物疎開区域名 } \\
\text { Evacuation area }\end{array}$ & \begin{tabular}{|c|} 
戦前都市計画街路 \\
Urban planning street before WWII
\end{tabular} & $\begin{array}{c}\text { 戦後都市計画街路 } \\
\text { Urban planning street after WWII }\end{array}$ & $\begin{array}{c}\text { 現在の街路名 } \\
\text { Current street name }\end{array}$ & $\begin{array}{l}\text { 備考 } \\
\text { Note } \\
\end{array}$ \\
\hline 1 & $\begin{array}{c}\text { 長町八本松 } \\
\text { Nagamachi-Hachihommatsu }\end{array}$ & $\begin{array}{c}\text { 土樋下河原線 } \\
\text { Tsutitoi-Simokawara Line }\end{array}$ & $\begin{array}{c}\text { 長町八本松線 } \\
\text { Nagamachi-Hachihommatsu Line }\end{array}$ & $\begin{array}{c}\text { 広瀬河畔通 } \\
\text { Hirosekahan dori Ave. }\end{array}$ & A \\
\hline 2 & $\begin{array}{c}\text { 東七番丁専売局角から南染師町六郷堀まで } \\
\text { From Monopoly Bureau(Higashinanabancho) } \\
\text { to Minamisomesimachi }\end{array}$ & - & $\begin{array}{c}\text { 連坊小路南染師町西線 } \\
\text { 連坊小路南染師町東線 } \\
\text { Rembokoji-Minamisomeshimachi east/west Line }\end{array}$ & - & B \\
\hline 3 & $\begin{array}{c}\text { 細横丁西側 } \\
\text { West side of Hosoyokocho }\end{array}$ & $\begin{array}{c}\text { 細横丁線 } \\
\text { Hosoyokocho Line }\end{array}$ & $\begin{array}{c}\text { 細横丁線 } \\
\text { Hosoyokocho Line }\end{array}$ & $\begin{array}{c}\text { 晚翠通 } \\
\text { Bansui dori Ave. }\end{array}$ & B \\
\hline 4 & $\begin{array}{l}\text { 青葉荘 日吉町 }(丁) \\
\text { Aobaso Hiyoshicho }\end{array}$ & $\begin{array}{c}\text { 仙台駅堤町線 } \\
\text { Sendai Sta.-Tsutsumimachi Line }\end{array}$ & $\begin{array}{c}\text { 仙台駅堤町線 } \\
\text { Sendai Sta.-Tsutsumimachi Line }\end{array}$ & $\begin{array}{c}\text { 愛宕上杉通 } \\
\text { Atago-Kamisugi dori Ave. }\end{array}$ & B \\
\hline
\end{tabular}

$A$ : 疎開跡地処理連絡街路事業によって計画 B: 戦災復興都市計画事業によって計画

A: Planned by street construction project in evacuation area B: Planned by war-damage reconstruction urban planning

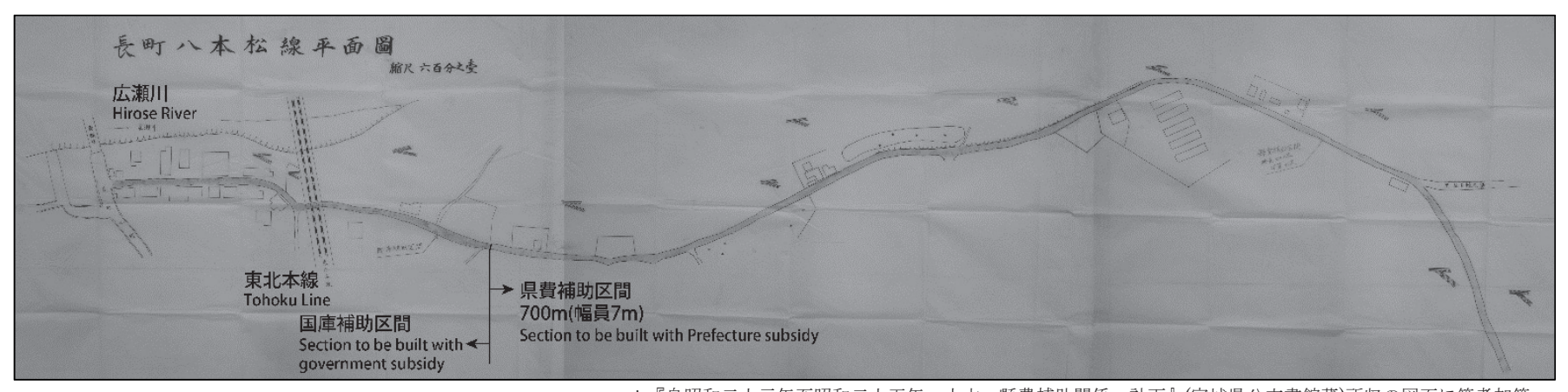

*『自昭和二十三年至昭和二十五年 土木 縣費補助関係 計画』(宮城県公文書館蔵)所収の図面に筆者加筆。

Fig.3 Plan of Nagamachi-Hachihommatsu Line

図 3 長町八本松線平面図 
工事は 1948 年 1 月 19 日から開始され、予定工期どおりに 2 月 29 日に竣功している76)。完成した街路は 1952 年 10 月 31 日に米軍が 撮影した空中写真77)に確認することができる。

以上のように、長町八本松における疎開跡地の都市計画転用は計 画から実施まで、スムーズに進行した。これには以下の 3 点が影響 を及ぼしたと考えられる。第 1 に、長町八本松における建物疎開は 疎開戸数が少なかった。そのため、疎開跡地の賃借や買収に必要な 費用が比較的少なかったと考えられる。第 2 に、長町八本松周辺は 1928 年に仙台市に編入された旧長町の区域にあたる新市域であり、 昭和 10 年代に相次いで建設された軍需工場の立ち並ぶ新興工業地

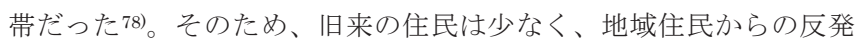
などが少なかったと考えられる。第 3 に、長町八本松における疎開 跡地整備は戦災復興都市計画事業によらず、疎開跡地処理連絡街路 事業として実施された。そのため、中央における戦災復興都市計画 の縮小や仙台中心市街地における復興事業の進捗などの周辺環境に 影響されることなく、十分な国庫・県費補助を得ることができた。 このような地域の性格および事業環境が疎開跡地の都市計画転用が 実施一と至る誘因になったと考えられる。

\section{2 .2 鉄道沿線疎開空地帯の転用計画}

鉄道沿線建物疎開は鉄道防護を目的として、東北本線・仙石線沿 線を対象に第 1 次および第 3 次建物疎開で計画された。このうち、 第 1 次建物疎開の東北本線沿線疎開空地帯(490 戸)は実施されてい たことが空中写真の分析から判明している79)。

鉄道沿線疎開空地帯の都市計画転用は長町八本松と同様に、1946 年度から仙台市都市計画課によって計画された80)。この時点では、 「小田原廣丁南染師町線」として計画されており、東北本線沿線疎 開空地帯の全域にわたって街路を敷設する予定だった ${ }^{81}$ 。実際に 1946 年度事業として進展したのは、東北本線疎開空地帯の南部にあ たる連坊小路から南染師町の間における沿線両側 $20 \mathrm{~m}$ ずつの街路 敷設のための測量のみであり、敷設計画も同区間 $1,200 \mathrm{~m}$ に縮小さ

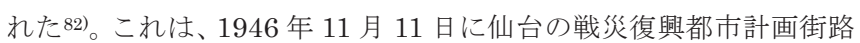
が決定したことによる。この街路計画において、連坊小路南染師町 西線および連坊小路南染師町東線が計画された。両路線の区間は連 坊小路跨線橋から七郷堀までの沿線両側で83)、幅員はいずれも $20 \mathrm{~m}$ だった。これによって、東北本線沿線疎開空地帯のうち南部(第 1 次 建物疎開の「東七番丁専売局角から南染師町六郷堀まで」の疎開空 地帯の一部)のみを戦災復興都市計画事業の一環として都市計画転 用することが計画決定された。

しかし、戦災復興都市計画街路網全体から考えると、これら 2 路 線は戦災非焼失区域である郊外で鉄道の両側に街路を設けるという 特殊な計画で、中心市街地の街路の広幅員化・新設、郊外との連絡 街路整備という全体方針とは明らかに異なっている。

このように、一見すると戦災復興都市計画としては計画意図の不 明瞭なものだが、この背景には 2.1 節で明らかにした中央省庁の疎 開跡地の処理方針が影響している。前述した「戦災地及建物疎開跡 地に於ける運輸省計画と都市計画に関する申合の件」では、鉄道沿 線両側に道路または緑地を設けること、新幹線等の鉄道施設計画の ある区間は計画線両側に道路を敷設することの 2 点を定めている。 この通牌は宮城県を経由して仙台市にも通知されていて、街路計画 に影響を与えたと考えられる ${ }^{84)}$ 。また、新聞報道によると、鉄道施
設計画としては仙台・博多間の弾丸列車計画が存在したとされる85)。 この計画は国鉄によって立案され、戦前の弾丸列車計画を引き継ぐ 形で仙台・博多間を、26 年後をめどに完成させるものである。その 後の報道はなく、『日本国有鉄道百年史』等の文献にもその記述は見 出せないため、構想の域を出るものではなかったと考えられるが、 用地確保というレベルでは、連坊小路南染師町線における疎開跡地 転用に影響を与えた可能性がある。

このように、連坊小路南染師町線は中央省庁の方針や思惑と結び つきながら立案されたが、その進捗は芳しくなかった。この計画に 対して県は、疎開跡地利用は都市計画上の好機であることから 1948 年度事業として街路整備を行う必要があるとの見解を、1947 年 9 月 29 日付の仙台市長あての文書で示している86)。一方、戦災復興の事 業主体である仙台市は、同年 10 月 27 日付の県土木部長への回答文 書で、近隣住民の反対を理由に街路計画を中止することを通知した。 市はこれに先立つ 7 月 25 日には既に疎開跡地の地主に対して、賃 借解除の通知をしており、市側に事業化の意思はなかったことが窥 える。その後、計画線としての両路線も 1954 年に幅員が $12 \mathrm{~m}$ に縮 小され、1966 年の街路網見直しの際に計画から除外された ${ }^{87) 。}$

以上のように、鉄道沿線疎開空地帯における疎開跡地の都市計画 転用は、政府や県は積極的な利用を促していたにもかかわらず、実 施には至らなかった。これには以下の 2 点が影響を及ぼしたと考え られる。第 1 に、鉄道沿線疎開空地帯の都市計画転用は戦災復興都 市計画に包含されていた。当時、戦災復興都市計画は前年に土地区 画整理区域や街路・公園計画の都市計画決定が行われたばかりであ り、その急速な実施が求められていた。しかし、初年度である 1946 年度事業は竣功を見る前に予算切れに陥り、1947 年 6 月になって やっと予算のめどが立ち工事を再開できるなど、中心市街地の区画 整理や街路敷設もままならない状態にあった 88 。 このような状況下 で中心市街地から外れた連坊小路南染師町線の工事に着手寸る余裕 はなかった。また、1947 年度をもって、疎開跡地の賃借への国庫補 助が打ち切られる予定だったことも影響していると考えられる。第 2 に、鉄道沿線疎開空地帯は旧城下町の範囲内で89)、家屋が密集し ていたため、疎開戸数が多かった。さらに、旧来の住民も多かった と推測される。そのため、事業化には多額の予算が見込まれ、かつ 疎開跡地利用に対する住民の反対の声も大きかった。こうした地域 の性格も疎開跡地の都市計画転用の中止に影響したと考えられる。

\subsection{3 中心市街地における利用}

中心市街地における疎開跡地処理の状況に関しては、現時点では 公文書等にその記述が確認できていない。また、空中写真による判 別も空襲による焼跡と疎開跡地の区別が困難であり、中心市街地に おける跡地処理の状況は現時点では不明である。しかし、建物疎開 対象区域と戦災復興街路の比較からの考察は可能である。

中心市街地では長町堤町線と細横丁線の 2 地区・2 路線で一致が みられる(図 $2 \cdot$ 表 3$)$ 。これら 2 路線は第 1 次建物疎開で消防道路整 備のために疎開が計画された区域と重なる90)。また、3.2 節で明らか にした仙台空襲直後の復興計画における街路計画にも含まれていた。 以上の点から、中心市街地においても、これら 2 路線で疎開跡地が 戦災復興都市計画街路に転用された可能性が示唆される。

\subsection{4 戦前都市計画街路との関係}

仙台における建物疎開区域指定の背景を考察した先稿によると、 
戦前・戦中期の中心市街地における都市計画の事業化が不十分だっ たことを背景として、仙台の建物疎開区域は先行する戦前都市計画 の影響を強く受けていた ${ }^{91)}$

それでは、戦前都市計画街路の路線と一致する形で指定された建 物疎開区域は、戦災復興都市計画においてどのように処理されたの だろうか。戦災復興都市計画街路と比較すると、中心市街地を主と して 3 地区・3 路線で両者の一致がみられる(図 2 ・表 3)。中でも、 中心市街地の仙台駅堤町線と細横丁線の 2 路線は、建物疎開計画に 先立つ防空土木施設整備計画から消防道路としての敷設が計画され ており、さらに仙台空襲直後の復興計画から一貫して計画され続け た路線でもある。また、長町八本松線は戦前都市計画街路を疎開跡 地の転用に合わせて延長している。その後、これら 3 路線はいずれ も戦災復興において街路敷設が実施されている。このようにして、 事業化が困難であった戦前都市計画街路のプランは建物疎開区域指 定を通して、戦災復興にまで引き継がれ、実現をみた。

\section{3 街路外用途の利用}

疎開跡地の戦後における転用は街路が主であったが、それ以外の 用途にも用いられていた。たとえば、京都では大規模駐車場や公園 緑地、駅前広場、庁舎用地などにも転用された ${ }^{92}$ 。

仙台では公園緑地への転用計画が存在しなかったことが、市の公 文書から判明している ${ }^{93)}$ 。この文書は内務省国土局計画課長からの 軍用跡地・疎開跡地の公園緑地への転用計画の有無に関する照会に 対する回答で、疎開跡地に関しては、転用計画はないと明記してい る。また、駅前広場や庁舎用地への転用計画なども確認されていな い。したがって、現時点では仙台における疎開跡地の恒久的利用を 見込んだ転用計画は街路のみだったと結論づけられる。

しかし、疎開跡地の一時的な利用としては、戦災復興期の食糧不 足への対策として、1947 年に疎開跡地を耕作地として利用する計画 が立案されていた94)。

\section{5. おわりに}

本稿では仙台を事例として、中央省庁の疎開跡地の処理方針や仙 台における戦災復興都市計画事業の進展などの疎開跡地処理を取り 巻く事業環境との関係に着目寸ることで、これまで考察されてこな かった疎開跡地処理の計画策定および実施の過程やその背景を明ら かにした。

戦時期に建物疎開を所管していた内務省は終戦直後から一貫して 疎開跡地の都市計画転用を強く推進していた。その方針は「戦災地 復興計画基本方針」にも盛り込まれ、戦災都市では主として戦災復 興都市計画事業の一環として疎開跡地の都市計画転用が行われるこ ととなった。また、非戦災都市では生産都市再建整備事業による転 用が実施された。ただし、戦後の混乱による事業の遅延やインフレ などの影響でそれらの計画は縮小を余儀なくされた。また、先行研 究では内務省の関与のみが注目されてきたが、鉄道沿線疎開空地帯 の処理に関しては、内務省のみならず運輸省や戦災復興院も都市計 画用地および鉄道用地一の転用を目論んでおり、仙台における連坊 小路南染師町西・東線の転用計画はその影響を強く受けていたと考 えられる。このほかにも、警視庁消防部も防火帯の確保を目的とし て、疎開跡地の空地や緑地、街路用地としての存置を要望していた。 仙台の疎開跡地処理は仙台空襲直後の復興計画から都市計画およ
び農政の二側面から構想されていた。このうち、都市計画的観点か らの疎開跡地の街路転用は戦後の計画に踏襲され、宮城県による当 初計画の策定から仙台市による最終案の決定に至るまで継承された。 また、戦災復興の策定過程ではその他の疎開跡地の転用も計画され、 鉄道沿線疎開空地帯は戦災復興都市計画事業の一環として、長町八 本松の疎開空地は疎開跡地処理連絡街路事業として立案された。し かし、事業化に至ったのは後者のみだった。これには、疎開戸数の 多宾やそれに伴う必要経費の違い、旧来の町屋が立ち並ぶ鉄道沿線 と工場・借家の多い新興工業地域である長町八本松という地域的な 性格の違い、中心市街地の事業進展に影響される戦災復興都市計画 事業と単一事業であり周辺状況に影響されない疎開跡地処理連絡街 路事業という事業環境・性格の違いなどが影響を及ぼしたと考えら れる。このように、疎開跡地処理の計画策定から実施もしくは中止 に至るまでの過程を詳細に把握することで、疎開跡地の都市計画転 用の成否を決定づける要因として、計画主体の変更や認識の差、事 業費目の違いなどの事業環境や当該地域の性格の相違などがあげら れることを示した。

最後に、戦前期から戦災復興期の各計画(戦前都市計画・建物疎開・ 戦災復興)間の関係をみると、3 路線で一致がみられた。これらは、 いずれも戦災復興において街路整備が行われており、事業化が困難 だった戦前都市計画街路のプランは建物疎開区域指定を通して、戦 災復興にまで引き継がれたという計画の連続性を窥うことができる。

なお、全国的な建物疎開の実施状況および戦後の跡地処理の実態 は未だ解明されていないが、この点については稿を改めて論じたい。

\section{謝辞}

本稿の執筆にあたって、宮城県公文書館、仙台市役所、仙台市博 物館、宮城県都市計画課、宮城県図書館、国立公文書館、国立国会 図書館から史資料を提供していただきました。とりわけ、菅野正道 氏(元仙台市博物館)には、資料の所在等に関して、貴重なご助言をい ただきました。ここに記して感謝申し上げます。

\section{注}

1）建設省編『戦災復興誌』第 1 巻計画事業編、財団法人都市計画協会、1959.3、 p.23(復刻版、大空社、1991.6)。

2）拙稿「仙台における建物疎開の実態と区域指定の背景 一建物疎開と先行 する諸計画の関係一」『日本建築学会計画系論文集』83(748)、2018.6、 pp.1143-1153。また、戦前都市計画と建物疎開の連続性は後述する広島、 名古屋、東京を対象とした研究でも指摘されている。

3）石田頼房『『戦災復興都市計画』研究の視点」『地域問題研究』15、1981.12、 p.2。

4）石丸紀興「建物疎開事業と跡地の戦災復興計画に及ぼした影響に関寸る研 究 一広島市の場合一」『日本都市計画学会学術研究論文集』24、1989.11、 pp.619-624。石丸紀興、井筒俊樹、中野司「長崎市における建物疎開とそ の跡地に関寸る研究」『日本建築学会中国支部研究報告集』10 (2)、1983.3、 pp.215-218、など。

5）越沢明『東京都市計画物語』日本経済評論社、1991.11。また、東京の場合 は東京都による戦災誌に建物疎開をはじめとした防空事業に関する詳細な 記述があり、越沢の研究もこれを参照している(東京都編『東京都戦災誌』、 1953.3)。

6) 後藤健太郎、佐藤圭二「名古屋市における戦中の防空対策が都市計画に及 ぼした影響」『日本都市計画学会学術研究論文集』25、1990.10、pp.469474 。

7）伊藤亮、大沢昌玄、岸井隆幸「横浜市における建物疎開の実態に関する研 究」『都市計画論文集』49(3)、2014.10、pp.1041-1046。

8）川口朋子『建物疎開と都市防空一「非戦災都市」京都の戦中・戦後』京都 
大学学術出版会、2014.3。

9) 闇市の形成過程や展開に関しては、初田や石槫らの研究に詳しい(初田香 成『都市の戦後 雑踏のなかの都市計画と建築』東京大学出版会、2011.5。 石槫督和『戦後東京と闇市 新宿 ・ 池袋 ・ 渋谷の形成過程と都市組織』鹿 島出版会、2016.9。橋本健二・初田香成編著『盛り場はヤミ市から生まれ た・増補版』青弓社、2016.1)。また、石槫は東京のターミナル駅周辺にお ける交通疎開空地と戦前の駅前広場計画の連続性を指摘している(前掲『戦 後東京と闇市 新宿・池袋・渋谷の形成過程と都市組織』、pp.54-66)。 以上の研究のほかにも、非戦災地方都市における疎開跡地処理を明らかに した高橋の研究がある(高橋舜「非戦災都市における建物疎開跡地の整備と 継承に関する研究 一生産都市再建整備事業に着目して一」『2016 年度優 秀卒業論文賞・優秀修士論文賞受賞論文梗概集』、2016、pp.89-92)。

10）内田らによる徳山の建物疎開を米軍撮影空中写真の分析によって把握す る研究や佐藤による弘前・福島・松山における建物疎開と都市計画の関係 に対する言及はこれまでにもあった(内田隆人、䅖吉啓太、工藤洋三「地方 都市における建物疎開の一事例」『日本建築学会中国支部研究報告集』32、 2009.3、pp.1-4。佐藤滋『城下町の近代都市づくり』鹿島出版会、1995.8)。 しかし、前者は空中写真の分析による疎開区域把握、後者は城下町都市の 近代化の契機のひとつとしての把握にとどまり、建物疎開事業の実態の詳 細な解明や都市計画転用の経緯などの考察には及んでいない。

11) 前注 2 。

12）越沢は京都や広島などの疎開跡地の都市計画転用が大々的に実施された 都市と比較して、東京は戦災復興都市計画の大幅な縮小もあり疎開跡地の 都市計画転用に失敗したと指摘している。その指摘の中で、玉川通りや環 状二号線は街路転用が構想されながらも実現しなかった事例としてあげら れている(前掲『東京都市計画物語』、pp.196-198)。

また、前述した石丸や川口による研究では、内務省が疎開跡地の都市計 画用地への転用を推進していたことは明らかにされている(石丸紀興「建物 疎開と戦災復興(3) (広島市戦災復興計画に関寸る研究 その 1)」『日本建築 学会中国支部研究報告集』8(1)、1980.10、pp.207-208。前注 8、pp.235-236)。 しかし、各都市における疎開跡地の都市計画転用の過程やその背景は考察 されていない。また、中央省庁の政策動向についても、内務省のみの把握 にとどまっている。

13）越沢明「近代日本都市計画における広幅員道路の系譜 $100 \mathrm{~m}$ 道路の起 源」『日本土木史研究発表会論文集』8、1988.6、pp.54-65 など。

14）永野聡、有賀隆「旧軍用地の都市公園への転用が公園緑地系統の計画 に与えた影響について一仙台市を事例として一」『日本建築学会計画 系論文集』77(675)、2012.5、pp.1077-1086。

15）事業の詳細に迫るものではないものの、『仙台市史』の戦災復興に関す る記述を基に、今後の仙台の戦災復興史研究の論点を整理した論考などは みられる(佐藤信夫「戦災復興史の再考」『市史せんだい』26、2016.9、pp.4458)。また、戦前都市計画との比較によって、戦災復興都市計画(街路計画や 用途地域など)の特色や両者の連続性を考察した浅野の論考は、全国各地の 地方都市 28 市を対象としているが、その中の一事例として仙台の戦災復 興都市計画が取り上げられている(浅野純一郎「地方都市の戦災復興都市計 画における街路計画の立案とその特色に関する研究 一戦前期の初期街路 計画との比較を通して一」『日本建築学会計画系論文集』76(667)、2011.9、 pp.1621-1630。浅野純一郎「地方都市の戦災復興都市計画における用途地 域指定の特色に関寸る研究 一戦前期の初期地域指定との比較を通して一」 『日本建築学会計画系論文集』79(696)、2014.2、pp.383-392。)。

16）仙台における疎開跡地処理については、拙稿「仙台における建物疎開跡 地処理 一戦時期仙台における防空都市計画に関する研究(その 2)一」(『日 本建築学会東北支部研究報告集・計画系』80、2017.6、pp.117-122)におい て考察している。本稿ではこれを踏まえ、以後の調査によって得られた新 たな知見を加えて、中央省庁の政策動向や仙台の戦災復興都市計画などと の関係を考察するために、先稿を再構成している。

17）防空総本部は 1943 年 10 月の防空法第 2 次改正を受けて同年 11 月に設 置された、内務省が主管する防空行政全般を担当した機関である。内務省 全体で防空行政にあたる体制を整備するとともに、外局とすることで省庁 横断的な性格を持つ防空行政を行うにあたり、各省との調整を容易にする ことを目的として設置された(大霞会内務省史編集委員会『内務省史』第 3 巻、1971.6、pp.510-511)。なお、のちに建物疎開を担当した施設局の局長 は後述する内務省国土局長の兼任とされた(大霞会内務省史編集委員会『内 務省史』第 4 巻、1971.6、p.651)。さらに、終戦時の防空総本部施設局建 物疎開課の課長は内務省国土局計画課長大橋武夫の兼任であり両課は事実 上一体となっていた(内政史研究会『大橋武夫氏談話速記録』、1972、 p.74(1972 年 2 月 9 日実施分)。小宮賢一「戦災復興事始めの記」、戦災復 興外誌編集委員会『戦災復興外誌』財団法人都市計画協会、1985.9、p.133。）。 このように、建物疎開をはじめとした防空総本部における防空都市計画と 内務省本省における一般都市計画は非常に強い一体的な関係を有していた。 18） 1937 年 10 月に防空法の施行に伴って設置され、都市計画・防空行政を 担っていた内務省計画局は、防空業務の増加によって 1941 年 9 月に国土 局と防空局に改組された。このとき都市計画と一般土木を担当することに なったのが内務省国土局である(前掲『内務省史』第 3 巻、pp.203-204)。な お、防空局は 1943 年 11 月に前述した防空総本部となった。

19）川口の研究によると、京都府公文書からは 1945 年 8 月 31 日付の国土局 通牒「建物疎開に関寸る件」が確認されている(前注 8、p.235)。

20）前掲『戦災復興誌』第 1 巻、p. 153 。

21）「戰災地復興計畫基本方針ノ件」『公文類聚・第六十九編・昭和二十年 · 第六十六巻 ・ 地理 ・ 土地 - 都市計画 ・ 建造物・疎開・警察』(国立公文書館 蔵)。

22）前掲『戦災復興誌』第 1 巻、pp.153-154。なお、詳細な内容は詳らかで ないが、1946 年 2 月 9 日に内務省は「建物疎開跡地処理に関する通牒」を 発しており、さらに同年 6 月 22 日にも「建物疎開跡地処理付て」を発して いて、内務省の疎開跡地の都市計画用地一の転用を強力に推進していた様 子が窺える(石丸紀興「建物疎開と戦災復興計画(1)～(3) (広島市戦災復興計 画に関する研究 その 1)」『日本建築学会中国支部研究報告集』8(1)、 1980.10、p.198,207)。

23）前掲『戦災復興誌』第 1 巻、pp.153-154。なお、仙台市所蔵の公文書に よると、この賃借費に対する国庫補助は 1947 年度限りで打ち切られる予 定となっていた(「疎開跡地の街路新設について」『昭和二十二年度 都市 計画関係書類』、仙台市役所蔵)。

24）前掲『戦災復興誌』第 1 巻、pp.398-399

25）戦時期日本において軍需物資などの戦争遂行に必要な物資の運搬を担う

鉄道の防護は、生産防空(生産機能の維持)という観点から重要視されていた。 そのため、全国各地で鉄道線路の両側もしくは片側の家屋を取り壊し、線 路沿いに帯状の空地帯を設けた事例が散見される。

26）日本国有鉄道『日本国有鉄道百年史』第 11 巻、1973.3、pp.314-317,347348 。

27）前掲『戦災復興誌』第 1 巻、p. 74 。

28）生産都市再建整備事業が実施された 166 都市中、12 都市は戦災都市の指 定を受けていたため、戦災都市の中にも生産都市再建整備事業による疎開 跡地の都市計画転用を行っていた都市は存在する(前掲「非戦災地方都市に おける建物疎開跡地の整備と継承に関する研究 一生産都市再建整備事業 に着目して一」、p.90)。宮城県の場合、塩䆤市は戦災都市かつ生産都市再 建整備事業実施都市だった(『官報』第 6661 号、1949 年 3 月 30 日、p.231)。 また、戦災復興都市計画事業とは別に、内務省国土局計画課所管の建物疎 開跡地整備事業を実施した都市も存在する。

29）戦時期には防空都市計画は防空総本部の所管だったが、終戦に伴い防空 総本部に包含されていた都市計画機構は内務省国土局計画課に一元化され た(前掲『戦災復興誌』第 1 巻、p.42)。

30) 内務省本省では 8 月 10 日ごろから日本の敗戦が伝えられ、計画課長の大 橋武夫は防空と建物疎開の業務を中止させ、戦災復興の企画立案にあたる ように指示していた(松井達夫「戦災復興計画回顧」、前掲『戦災復興外誌』、 p.107。前掲『東京都市計画物語』、p.201。)。

31）戦災復興院は 1947 年 12 月 31 日の内務省の解体に伴って、内務省国土 局と合して建設院に改組された。さらに、1948 年 7 月 10 日には建設省と なった(前掲『戦災復興誌』第 1 巻、pp.729-741)。

32）前掲『内務省史』第 3 巻、pp.208-209

$33)$ 前掲『戦災復興誌』第 1 巻、p. 2 。

34) 前掲『戦災復興誌』第 1 巻、p. 25 。

35）「生産都市再建整備事業費及び地下土木施設整理事業費國庫補助内定に ついて」『昭和二十一年 土木 地下土木施設整理事業 別(前編) 防空土 木施設関係』(宮城県公文書館蔵)。

36）前注 28 。ただし、前掲の高橋の研究は官報の分析によって事業対象都市 を明らかにしており、官報への記載がなかった都市は把握していないため、 実際にはより多くの都市が事業対象とされた。宮城県の場合、石巻市や古 川町、白石町なども事業対象とされており、そのうち石巻市では疎開跡地 を対象とした事業が計画された(『昭和二十二年 土木 計画 生産都市再 建整備事業』、宮城県公文書館蔵)。

37）前掲『内務省史』第 3 巻、p.209。宮城県の場合、古川町や白石町、渡波 町、鮎川町、鳴子町、多賀城村の 5 町 1 村で疎開跡地を対象としない街路 
整備が生産都市再建整備事業によって実施された(『昭和二十二年 土木 計画 生産都市再建整備事業』・『昭和二十三年 土木 生産都市再建整 備事業』・『昭和二十三年 土木 生産都市再建整備事業(前編)』、いずれ も宮城県公文書館蔵)。

38）前掲『内務省史』第 3 巻、p.209。

39) 前掲『戦災復興誌』第 1 巻、pp.642-650。

40）石田頼房『日本近代都市計画の百年』自治体研究社、1987.1、pp.230-231。

41）仙台における建物疎開の実施に至る経緯や区域指定の詳細・背景、実施 状況などについては、前掲「仙台における建物疎開の実態と区域指定の背 景 一建物疎開と先行する諸計画の関係一」において詳述している。

42）前掲「仙台における建物疎開の実態と区域指定の背景 一建物疎開と先行 する諸計画の関係一」、pp.1145-1148。

43）「近ク實行セントスル重要事項 土木部計畫課」『昭和二十年十月二十七 日 知事事務引継書 引継者生悦住求馬 引受者千葉三郎』(宮城県公文書 館蔵)。仙台市開発局『仙台市戦災復興誌』、1981.3、pp.28-29。

44）前掲「仙台における建物疎開の実態と区域指定の背景 一建物疎開と先行 寸る諸計画の関係一」、p. 1148 。

45）『河北新報』1945 年 7 月 26 日、第 2 面。

46）被災者の救護対策は 7 月 11 日の段階から報じられていた(『河北新報』 1945 年 7 月 11 日、第 2 面)。

47）『河北新報』 1945 年 7 月 16 日、第 2 面。

48）『河北新報』 1945 年 7 月 18 日、第 2 面。同 7 月 21 日、第 2 面。

49）戦災や疎開による都市人口の減少の影響で都市活動の維持が困難になる 状況を解決するために、都市にコミュニティを再建し、都市人口を増や寸 ために計画され、その背景には近隣住区概念があったと指摘されている(越 沢明『復興計画』中央公論新社、2005.8、pp.149-150)。

$50 ）$ 『河北新報』 1945 年 7 月 21 日、第 2 面。

51）前注 45 。

52）『河北新報』1945 年 7 月 29 日、第 2 面。

53）中心市街地における建物疎開の実施状況は史料的制約のため、現時点で は詳らかではない(前注 44)。

54）『河北新報』1945 年 8 月 4 日、第 2 面。

55）公会は 1940 年に紀元二千六百年記念事業の一環として設けられた地域 組織で、防空や市政情報の伝達、納税、配給など幅広い業務を担当し、戦 時下における市民生活統制の役割を担った(「昭和二十一年四月今村市長退 職事務引継書 公會係」『昭和二十年度同二十三年度 旧公会地区出張所 関係書類＼cjkstart庶務課』・仙台市博物館蔵)。公会の下には隣組が組織され、1940 年 9 月の「部落会町内会等整備要綱」に基づいて全国に組織された、部落 会・町内会・隣組と同様の役割を果たした。仙台における建物疎開では疎 開者への説明や疎開者からの相談への対応に公会長があたるなど、事業施 行の際に公会の果たした役割は非常に大きかった(拙稿「仙台における建物 疎開の執行機関と実施過程 一戦時期仙台における防空都市計画に関する 研究（その 4) 一」『日本建築学会大会学術講演梗概集(建築歷史・意匠)』 (東北)、2018.7、pp.133-134)

56）『河北新報』 1945 年 8 月 13 日、第 2 面。

57）「戰災地應急復興対策要領」『昭和二十年 農政 農村整備関係』(宮城 県公文書館蔵)。

58）「戰災地應急復興対策要領」には「防空空地」と記されている。防空空地 は厳密には建物疎開空地とは異なり、建築物の撤去は伴わない、建築を禁 止する区域のことであり、東京や大阪で指定されたことが知られている。 しかし、仙台では防空空地は指定されていない。また、当時の防空行政の 現場では、しばしば防空空地と建物疎開空地を混同して使用している例が 認められる(前注 8、pp.97-99)。そのため、本稿では「戰苂地應急復興対策 要領」の記述は建物疎開空地を指しているとみなした。

59）仙台市史編さん委員会編『仙台市史』通史編 8 現代 1、2011.5、p.121。

60）『河北新報』1945 年 11 月 17 日、第 2 面。

61）『河北新報』 1945 年 11 月 12 日、第 1 面。

62 )『河北新報』 1945 年 12 月 10 日、第 2 面。

$63 ）$ 『河北新報』 1946 年 2 月 8 日、第 2 面。

64）仙台市開発局編『戦災復興余話』宝文堂、1980.3、p.20。

$65 ）$ 『河北新報』1946 年 9 月 30 日、第 2 面。

なお、この間の 1946 年 5 月 9 日に土地区画整理施行区域の決定は実施さ れている(前掲『仙台市戦災復興誌』、p.75)。

66) 前注 $59 、$ p. 122 。

67）「仙台市復興都市計画街路及公園決定」『自昭和二十一年度至昭和二十三 年度 都市計画宮城地方委員会計画課』(宮城県都市計画課蔵)。
68）仙台市土木部都市計画課『仙台市都市計画』、1956.9、「告示関係資料」。 69）前掲『仙台市戦災復興誌』、pp.60-63。

70）「仙臺市會議事速記錄 第一號 昭和二十一年二月二十三日」『仙台市議 会会議録 昭和二十一年』、p.7(仙台市議会事務局蔵)。

71）『仙臺市公報』第二百五十一號(1947 年 2 月 15 日)、第 2 面(仙台市役所 蔵)。

72）『自昭和二十三年至昭和二十五年 土木 縣費補助関係 計画』(宮城県 公文書館蔵)

73）同上史料所収。

74）「昭和二十二年度疎開跡地處理連絡街路事業県費補助申請について」、前

掲『自昭和二十三年至昭和二十五年 土木 縣費補助関係 計画』。

75）「仙臺市會議事速記錄 第一號 昭和二十二年二月二十八日」『仙台市議 会会議録 昭和二十二年』、p.8(仙台市議会事務局蔵)。「仙臺市會議事速 記錄 第三號 昭和二十二年三月五日」、同史料、p.18。

76）「昭和二十二年度疎開跡地處理連絡街路事業竣功認定について申請」、前 掲『自昭和二十三年至昭和二十五年 土木 縣費補助関係 計画』。

77) 米軍撮影空中写真「USA-M174-360」(1952.10.31 撮影)、9,909 分 1、国土地理 院「地図・空中写真閲覧サービス」(http://mapps.gsi.go.jp/maplibSearch.do?specifi cationId=7423)

78）仙台市史編さん委員会編『仙台市史』通史編 7 近代 2、2009.7、pp.135142 。

79）東北本線沿線の「元寺小路 X橋からキリンビール会社(小田原広丁)まで」

と「東七番丁専売局角から南染師町六郷堀まで」の 2 区域の沿線両側 $30 \mathrm{~m}$ ずつ(あわせて $60 \mathrm{~m}$ 幅・合計 490 戸)の疎開計画だった(前注 2、pp.1145 1148)。

80) 前注 70 。

81） 1946 年 7 月 10 日の段階では綜合土木事業計画として、東北本線沿線の 行人塚から連坊小路および連坊小路東仙台駅の沿線両側(いずれも片側幅 員 $20 \mathrm{~m}$ )の合計 4 本の街路が計画されており、東北本線沿線疎開空地帯全 域の街路計画が維持されていた。このほかにも、同じく鉄道沿線疎開空地 帯として計画されていた仙石線沿線の仙台駅東口から原町駅までの沿線両 側(片側幅員 $20 \mathrm{~m}$ )に対して街路建設が構想されている。しかし、この計画 は単なる構想で終わった(「綜合土木事業計画調査について」、前掲『昭和 二十二年度 都市計画関係書類』)

82) 前注 71 。

83） 1946 年度事業として進展した連坊小路から南染師町の間にあたる。

84）「仙台驛前土地区画整理に伴う仙台鉄道局管理部等建築物の整理移転に ついて」、前掲『昭和二十二年度 都市計画関係書類』。

85）『河北新報』1945 年 11 月 20 日、第 1 面。

86）「疎開跡地の街路新設について」、前掲『昭和二十二年度 都市計画関係 書類』。

87）前掲『仙台市戦災復興誌』、pp.60-63,321-337。

88 )『河北新報』 1947 年 6 月 29 日、第 2 面。

89）「元寺小路 $\mathrm{X}$ 橋からキリンビール会社(小田原広丁)まで」の地域は仙台 城下町の範囲内であり、「東七番丁専売局角から南染師町六郷堀まで」の 地域は、1627 年 2 月に仙台城下町東南部に建設が開始された若林城の城下 町にあたる地域である(仙台市史編さん委員会編『仙台市史』通史編 3 近世 1、2001.9、pp.108-112。同『仙台市史』通史編 4 近世 2、2003.2、pp.183186 。)

90)「細横丁西側」と「青葉荘〜日吉町(丁)」の 2 区域にあたる(前注 $2 、 p p .1145$ 1148)

91）前注 2、p. 1150 。

92）建設局小史編さん委員会編『建設行政のあゆみ 一京都市建設局小史一』、 1983.3、pp.55-56 ・ 附図「建物疎開跡地利用計画図」。前注 8、p. 272 。

93）「軍用跡地建物疎開跡地の調査並に昭和二十三年度観光都市整備事業に

関寸る件」、前掲『昭和二十二年度 都市計画関係書類』。

94）「復興土地区画整理区域站に疎開跡地の耕作利用について」『昭和二十二

年 土木 復興土地区画整理事業 計画』(宮城県公文書館蔵)。 


\section{THE DISPOSITION OF BUILDING EVACUATION SITES IN SENDAI AND WAR-DAMAGE RECONSTRUCTION}

- The projects and the relationship among public entities over diversion of evacuation sites to urban planning sites -

\section{Shunsuke SAITO*1}

${ }^{* 1}$ Grad. Student, Graduate School of Human and Environmental Studies, Kyoto University

The purpose of this paper is to clarify the state of the disposition of building evacuation sites in Sendai and its process and background while paying attention to business environments surrounding the disposition of building evacuation sites such as the central government's policy for the disposition and the progress of the war-damage reconstruction urban planning in Sendai.

Home Ministry, which had been responsible for building evacuation during the wartime period, has consistently promoted diversion of evacuation sites to urban planning immediately after the end of WWII. Ministry of Transport and War-Damage Reconstruction Institute also planned to divert evacuation sites to urban planning sites and railway land. It is thought that the street plan of Rembokoji-Minamisomeshimachi west and east Line in Sendai was strongly influenced by such a policy of Ministry of Transport and War-Damage Reconstruction Institute.

The disposition of building evacuation sites in Sendai was schemed from two aspects of urban planning and agricultural policy, from the war-damage reconstruction plan immediately after Sendai air raid. Among them, the diversion of evacuation sites to streets in the context of urban planning was followed by the plan after the war, and it was succeeded from the initial plan by Miyagi prefecture to the final plan of Sendai city. In the process of formulating the war-damage reconstruction plan, other diversion was also planned. Rembokoji-Minamisomeshimachi west and east Line was planned as part of the war-damage reconstruction urban planning project in the building evacuation site along the railway tracks of Tohoku Line. Nagamachi-Hachihommatsu Line was also planned as "SokaiatochishoriRenrakugairo-zigyo" project. However, only the latter was completed. There are three reasons why all the streets were not completed. First of all, the number of evacuated houses was different, and accordingly there was a difference in construction costs. Second of all, regional characteristics were different. Many old houses stood near the railway, but Nagamachi-Hachihommatsu was a new industrial area with factories and leased houses. Third of all, the environment and characteristics of the disposition of building evacuation sites differed. Rembokoji-Minamisomeshimachi west and east Line was one of the war-damage reconstruction urban planning project affected by the progress of business in the center of Sendai city, but Nagamachi-Hachihommatsu Line was a single project and was not affected by surrounding conditions.

Considering the relationship between war-damage reconstruction and prewar urban planning and building evacuation, three streets coincided with preceding plans, and the prewar urban planning streets were succeeded to wardamage reconstruction through building evacuation. As described above, you can see the continuity of urban planning through building evacuation. 